\title{
EVALUASI PELATIHAN TEKNIK PENANAMAN CEMPAKA BERDASARKAN TEORI THE FOUR LEVELS KIRKPATRICK
}

\author{
Arif Irawan ${ }^{1 *}$, Hanif Nurul Hidayah ${ }^{1}$, A. Wildah ${ }^{1}$ \\ ${ }^{1}$ Balai Penelitian dan Pengembangan Lingkungan Hidup dan Kehutanan Manado, Jl. Tugu Adipura Raya, \\ Manado, Sulawesi Utara \\ * corresponding author | email : arif_net23@yahoo.com
}

Cempaka (Elmerrillia sp.) merupakan jenis kayu yang memiliki keterikatan erat dengan budaya masyarakat suku Minahasa karena digunakan dalam pembuatan rumah adat. Pasokan bahan baku kayu cempaka sudah semakin terbatas karena keberadaannya sudah semakin berkurang. Salah satu hal yang dapat dilakukan untuk mendukung kegiatan pemanfaatan cempaka adalah melalui penyebarluasan informasi melalui kegiatan pelatihan teknik penanaman cempaka. Penelitian ini bertujuan untuk melakukan evaluasi kegiatan pelatihan tenik penanaman cempaka berdasarkan teori The Four Levels yang dikembangkan oleh Kirkpatrick pada level I dan II. Pengumpulan data dilakukan dengan wawancara terhadap seluruh peserta kegiatan pelatihan dari 3 (tiga) kabupaten (Minahasa, Minahasa Utara, dan Minahasa Selatan) dengan jumlah peserta masing-masing kabupaten adalah berjumlah 15 orang. Data untuk evaluasi pada level 1 ditabulasi dan selanjutnya dianalisis secara deskriptif. Evaluasi pada level 2 dilakukan dengan membandingkan data hasil kuesioner pre-test dan post-test menggunakan uji t sampel berhubungan. Hasil penelitian menunjukkan bahwa pelatihan teknik penanaman cempaka dapat terlakasana dengan baik (evaluasi level 1). Pelatihan mampu meningkatkan pengetahuan peserta yang ditandai dengan adanya peningkatan nilai hasil evaluasi dari kuesioner sebelum dan setelah pelatihan sebesar 22 persen di Kabupaten Minahasa; 20 persen di Kabupaten Minahasa Utara, dan 13 persen di Kabupaten Minahasa Selatan (evaluasi level II).

\section{Kata Kunci : cempaka (Elmerrillia sp.), evaluasi, pelatihan, analisis Kirkpatrick}

Cempaka (Elmerrillia sp.) is a type of woods that has a close attachment to the culture of the Minahasa community because it is used in the making of traditional houses. The supply of cempaka wood raw materials has become increasingly limited because its existence has diminished. One of the things that can be done to support the preservation of cempaka is with the dissemination through training in cempaka planting techniques. This study aims to evaluate the training activities of cempaka planting techniques based on The Four Levels theory developed by Kirkpatrick at level I and II. Data collection was carried out by interviewing all training participants from 3 (three) districts (Minahasa, North Minahasa, and South Minahasa) with 15 participants in each district. Data for evaluation at level 1 were tabulated and then analyzed descriptively. Evaluation at level 2 is carried out by comparing the results of the pre-test and post-test questionnaire using the corresponding sample $t$ test. The results showed that the training in cempaka planting techniques was carried out well (level 1 evaluation). The training was able to increase participants' knowledge which was marked by an increase in the value of the evaluation results from the questionnaire before and after the training by 22 percent in the Minahasa District; 20 percent in North Minahasa District, and 13 percent in South Minahasa District (level Il evaluation). 
Salah satu jenis kayu yang banyak digunakan oleh masyarakat Sulawesi Utara adalah jenis kayu cempaka (Elmerrillia sp.). Kayu ini memiliki banyak peruntukan di antaranya adalah sebagai bahan furnitur, lemari, pintu, dan alat musik kulintang (Kinho \& Mahfudz, 2011). Kayu cempaka memiliki tekstur kayu yang khas yang tidak dimiliki jenis kayu yang lain. Cempaka juga merupakan jenis kayu yang memiliki keterikatan erat dengan budaya masyarakat suku Minahasa. Kayu cempaka digunakan sebagai bahan baku utama utama dalam pembuatan rumah adat khas Minahasa. Lumempouw (2014) menyatakan bahwa dalam proses upacara adat pembuatan rumah di daerah Tombulu (salah satu suku di Minahasa), kayu cempaka adalah kayu yang dicari di hutan untuk digunakan sebagai bahan utama pembuatan rumah. Sejak dahulu pohon cempaka merupakan jenis pohon yang mendominasi kawasan-kawasan hutan di daerah Minahasa.

Pelestarian cempaka sebagai tanaman hutan penghasil kayu perlu terus dilakukan mengingat kebutuhannya yang terus meningkat. Pasokan bahan baku kayu cempaka dengan kualitas yang baik hingga saat ini masih mengandalkan pasokan dari hutan alam. Pasokan bahan baku dari hutan alam sudah semakin terbatas karena populasinya sudah semakin berkurang. Sasmuko (2010) menyatakan bahwa kebutuhan kayu cempaka yang berasal dari hutan alam dan hutan rakyat sebagai bahan utama pembuatan rumah adat Minahasa sudah semakin terbatas. Berdasarkan permasalahan ini maka kegiatan pemanfaatan cempaka perlu menjadi prioritas mengingat tingkat kebutuhannya yang cukup tinggi untuk masyarakat Minahasa.

Salah satu hal yang dapat dilakukan untuk mendukung kegiatan pelestarian cempaka adalah melalui penyebarluasan informasi mengenai teknik budidayanya. Tanaman cempaka merupakan salah satu tanaman yang memiliki karakter khusus, diantaranya sangat sensitif terhadap perubahan kondisi lingkungan. Penanganan bibit cempaka yang tidak tepat serta kesalahan perlakuan dalam kegiatan penanaman dapat meningkatkan resiko kerusakan bibit dan menyebabkan kematian bibit. Informasi mengenai teknik penanaman cempaka yang sesuai perlu diketahui masyarakat sehingga keberhasilan pembangunan tegakan cempaka di Sulawesi Utara dapat terlaksana sesuai harapan.

Intenational Tropical Timber Organisation (ITTO) melalui Proyek PD 646/12. Rev. 3 (F) "Initiating the Conservation Cempaka Tress Species (Elmerrillia sp.) through Plantation Development with the Local Community Participation in North Sulawesi" telah melakukan kegiatan pelatihan mengenai teknik penanaman cempaka untuk masyarakat di 3 (tiga) Kabupaten di Sulawesi utara, yaitu Kabupaten Minahasa, Kabupaten Minahasa Utara, dan Kabupaten Minahasa Selatan. Penelitian ini bertujuan untuk melakukan evaluasi kegiatan pelatihan teknik penanaman cempaka berdasarkan teori The Four Levels yang dikembangkan oleh Kirkpatrick pada level I dan II. Salah satu model evaluasi yang umum digunakan untuk melakukan evaluasi terhadap kegiatan pelatihan adalah Kirkpatrick Analysis. Metode ini merupakan model evaluasi pelatihan yang dikembangkan pertama kali oleh D. Kirkpatrick pada tahun 1959. Kirkpatrick Analysis mengidentifikasi empat level yang berbeda untuk melakukan evaluasi pelatihan. Keempat level tersebut yaitu Level 1 (Reaksi); level 2 (Pembelajaran); Level 3 (Perilaku); dan Level 4 (Hasil).

\section{METODE}

Penelitian dilaksanakan pada bulan November - Desember Tahun 2019 terhadap masyarakat peserta pelatihan dari Kabupaten Minahasa, Minahasa Utara, dan Minahasa Selatan. Data yang dikumpulkan adalah data primer dan data sekunder. Dalam pengumpulan data digunakan wawancara dengan alat bantu kuesioner, studi pustaka dan dokumentasi. Pengumpulan data dilakukan terhadap seluruh peserta kegiatan pelatihan dengan jumlah peserta masing-masing kabupaten berjumlah 15 orang.

Metode analisis data yang digunakan adalah menggunakan pendekatan kualitatif dan kuantitatif. Evaluasi pada level 1 menggunakan metode kualitatif. Data hasil kuesioner mengenai hal yang berkaitan dengan teknis pelatihan ditabulasi dan selanjutnya dianalisis secara deskriptif. Evaluasi pada level 2 menggunakan metode kuantitatif. Evaluasi ini dilakukan dengan melakukan input data hasil kuesioner pre test dan post test dalam bentuk tabel Excel terkait informasi-informasi yang 
disampaikan saat pelatihan. Data dianalisis dengan memberikan nilai skor pada masing-masing pertanyaan dengan nilai maksimal 1300 dan minimal 0 . Ada tidaknya perubahan pengetahuan peserta sebelum dan setelah pelatihan dapat dihitung dengan menggunakan rumus sebagai berikut.

$\frac{\text { Jumlah skor sebelum pelatihan-Jumlah skor setelah pelatihan }}{\text { Jumlah total skor maksimal }} x 100 \%$

Data yang diperoleh dari hasil kuesioner selanjutnya dianalisis menggunakan uji t sampel berhubungan serta secara deskriptif. Data hasil analisis ditampilkan dalam bentuk output data pengolahan data, tabel dan gambar.

\section{HASIL DAN PEMBAHASAN}

Kepuasan peserta pelatihan (evaluasi level I) dalam penelitian ini dikaji dari empat aspek yaitu: (a) kepuasan peserta terhadap materi pelatihan (kemudahan materi untuk dipahami, kesesuaian materi, keterorganisiran materi); (b) kepuasan peserta terhadap fasilitator pelatihan (kapabilitas pemateri, alokasi waktu penyampaian); (c) kepuasan peserta terhadap metode pelatihan (metode diskusi/tanya jawab, alokasi waktu, jawaban yang diberikan pemateri); dan (d) kepuasan peserta terhadap fasilitas/sarana prasarana pelatihan yang disediakan. (fasilitas ruang pelatihan, konsumsi, lokasi pelatihan). Rekapitulasi data hasil evaluasi teknis level I ini ditampilkan pada Gambar 1.

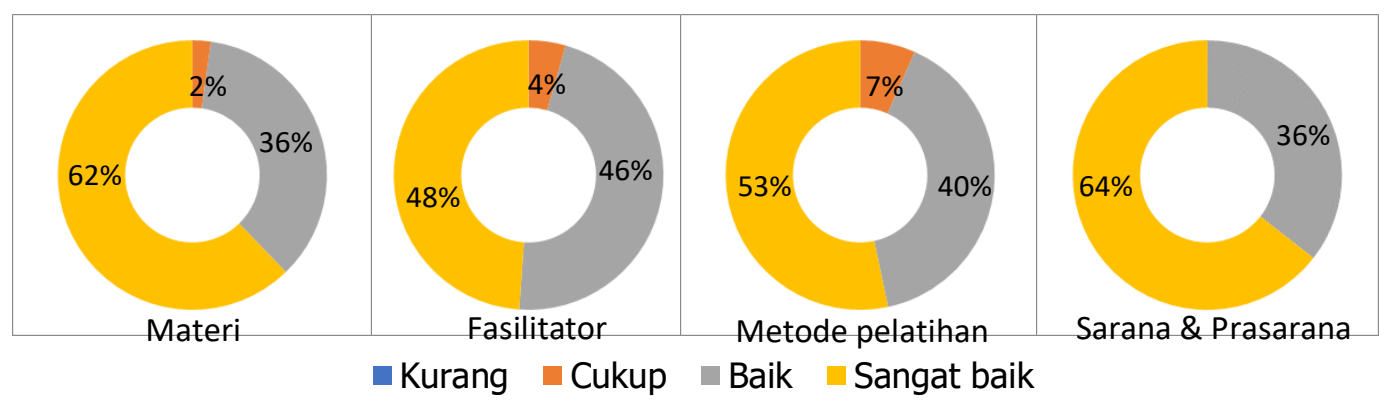

Gambar 1. Hasil Evaluasi Pelaksanan Pelatihan

Untuk mengetahui pengetahuan yang diperoleh peserta pelatihan pada masing-masing kabupaten dilakukan analisis menggunakan uji t sampel berhubungan yang ditampilkan pada Tabel 1.

Tabel 1. Hasil Analisis Uji T Sampel Berhubungan dan Nilai Rata-Rata

\begin{tabular}{lllll}
\hline Kabupaten & Nilai uji t & sig & Nilai rata-rata pre test & Nilai rata-rata pos test \\
\hline Minahasa & $-3,671$ & 0,003 & 839 & 1.025 \\
Minahasa Utara & $-2,809$ & 0,014 & 762 & 919 \\
Minahasa Selatan & $-2,449$ & 0,028 & 967 & 1.099 \\
\hline
\end{tabular}

Perbandingan hasil rekapitulasi pertanyaan-pertanyaan yang diberikan kepada peserta pelatihan dalam pre test dan post test ditampilkan pada Gambar 2.

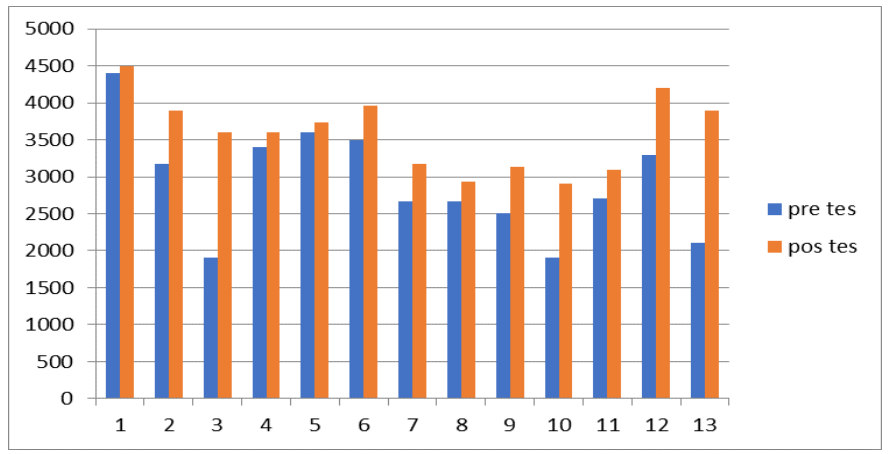

Gambar 3. Hasil Rekapitulasi Setiap Pertanyaan Sebelum dan Setelah Pelatihan 
Pelatihan adalah proses untuk mencapai kemampuan tertentu dalam rangka membantu mencapai tujuan yang diharapkan (Sulaefi, 2017). Salah satu tujuan dari kegiatan pelatihan adalah penguatan kapasitas yang dimiliki masyarakat (Wardhani et al., 2015). Pelatihan memberikan pengaruh positif terhadap hasil kinerja sebuah organisasi (Tahir et al., 2014; Sultana et al., 2012; Falola, et al., 2014). Pelatihan teknik penanaman cempaka diharapkan mampu meningkatkan kapasitas masyarakat dalam mengembangkan tanaman cempaka sehingga pada akhirnya memberikan dampak terhadap peningkatan minat masyarakat untuk menanam tanaman cempaka pada lahan pasini (lahan pribadi) untuk mengatasi permasalahan ketersediaan pasokan kayu cempaka yang berkualitas.

Beradasarkan Gambar 1 dapat diketahui bahwa pelaksanan pelatihan teknik penanaman cempaka terlaksana dengan baik. Terkait materi yang disampaikan sebagian besar peserta menyatakan materi telah sesuai yang diharapkan oleh peserta pelatihan. Fasilitator cukup interaktif dengan teknis peyampaian yang bervariasi (teori dan praktek). Metode pelatihan juga mendapat tanggapan yang baik, metode yang disampaikan didominasi kegiatan tanya jawab yang memberikan ruang bagi peserta untuk memperdalam materi yang disampaikan. Sarana dan prasarana yang disediakan juga sangat memuaskan bagi peserta.

Meiyla \& Syamsi (2015) menyatakan bahwa perbedaan tingkat kepuasan pada masing-masing peserta pelatihan pada level 1 lebih disebabkan oleh perbedaan karakteristik masing-masing peserta pelatihan. Tingkat kepuasan seseorang dalam menilai suatu hal tergantung dari persepsi, harapan, dan ketertarikan dari orang tersebut (Yuliarmi, 2007). Tingkat ketertarikan yang tinggi serta persepsi yang baik terhadap pelasanaan pelatihan teknik penanaman cempaka ini merupakan modal yang berharga atas terlaksananya dengan baik kegiatan ini. Kedua hal tersebut memberikan pengaruh positif terhadap hasil evaluasi pada level I dari pelatihan yang telah terlaksana.

Namun demikian terdapat beberapa catatan kecil yang disampaikan peserta terkait kegiaan pelatihan ini antara lain terkait keterlambatan waktu dimulainya pelaksanaan kegiatan pelatihan karena menunggu peserta lain yang belum hadir. Antisipasi terhadap kondisi hujan saat kegiatan praktek (outdoor) juga perlu dipersiapkan diantaranya dengan menyediakan jas hujan bagi peserta. Penambahan jumlah peserta, utamanya peserta dari kalangan muda, sehingga mampu meningkatkan minat untuk mengembangkan cempaka di masa depan. Materi juga dapat ditampilkan lebih banyak secara visual/video serta kegiatan praktek/lapangan untuk menghilangkan kejenuhan.

Utomo \& Tehupeiory (2014) menyatakan bahwa evaluasi pelatihan level II dilakukan untuk mengukur seberapa jauh peserta pelatihan menyerap dan memahami materi yang diberikan oleh instruktur. Evaluasi level II pada pelatihan ini bertujuan untuk mengetahui tingkat informasi yang disampaikan dalam kegiatan pelatihan teknik penanaman cempaka. Evaluasi ini didasarkan pada hasil rekapitulasi nilai post test dan pre test.

Berdasarkan Tabel. 2 dapat diketahui bahwa ketiga kabupaten memiliki nilai sig $<0,05$, hal ini berarti bahwa secara statistik terdapat perbedaan signifikan pengetahuan peserta sebelum dilaksanakan pelatihan (pre test) dan setelah dilaksanakan kegiatan pelatihan (pos test). Jika dibandingan lebih lanjut nilai rata-rata pos test lebih tinggi dibandingkan dengan nilai rata-rata pre test. Nilai ini mengindikasikan bahwa kegiatan pelatihan teknik penanaman cempaka yang telah dilakukan mampu secara efektif meningkatkan pengetahuan yang dimiliki peserta pelatihan dari 3 (tiga) kabupaten.

Peningkatan pengetahuan setelah dilakukan kegiatan pelatihan cukup bervariasi antarkabupaten. Peserta pelatihan dari Kabupaten Minahasa mengalami peningkatan pengetahuan sebesar 22\%, peserta dari Kabupaten Minahasa Utara meningkat sebesar 20\%. dan peserta dari Kabupaten Minahasa Selatan meningkat sebesar 13\%.

Pemanfaatan tanaman cempaka menggunakan pola agroforestry juga tidak banyak diketahui peserta sebelum pelaksanaan pelatihan. Premono \& Lestari (2013) menyatakan bahwa pola penanaman campuran (agroforestry) merupakan bentuk efisiensi yang dilakukan petani dengan tujuan untuk mengurangi biaya dan menambah keragaman hasil lahan. Melalui pengembangan pola agroforestry, masyarakat masih dapat memperoleh hasil tanaman musiman secara berkelanjutan 
tanpa berpengaruh signifikan terhadap pertumbuhan tanaman utama. Pola ini juga mampu memberikan solusi bagi terbatasnya lahan yang dimiliki masyarakat terkait keinginannya melestarikan tanaman cempaka. Komoditas yang berpotensi untuk dikembangkan menggunakan pola ini adalah penanaman jenis vanili dibawah tegakan cempaka. Jenis ini memiliki potensi yang baik, mengingat banyak masyarakat yang saat ini mengembangkannya. Selain manfaat ekonomi keberadaan jenis tanaman sela mampu memberikan kontribusi terhadap pertumbuhan tinggi dan diameter cempaka. Handayani \& Junaidi (2014) meyatakan bahwa pola agroforestry dapat meningkatkan kandungan karbon organik dalam tanah, sehingga berakibat meningkatkan porositas tanah dan kapasitas lapang. Lebih lanjut disampaikan bahwa dampak pola tanam agroforestry sengon bersifat positif terhadap pertumbuhan tegakan sengon khususnya meningkatkan diameter dan tinggi pohon sengon. Selain itu Mindawati et al., (2013) juga mayampaikan bahwa pola agroforestry mampu memberikan hasil pertumbuhan sengon yang terbaik dibandingkan dengan monokultur sengon.

Pada dasarnya sebagian besar peserta pelatihan telah memiliki pengetahuan awal mengenai tanaman cempaka, namun dengan tingkatan yang berbeda-beda jika diklasifikasikan berdasarkan asal Kabupaten. Wilayah Kabupaten Minahasa Selatan dikenal sebagai wilayah penghasil kayu cempaka. Masyarakat telah mengembangkan tanaman cempaka secara turun temurun. Berdasarkan penelitian Nangi \& Pelealu (2016), Kabupaten Minahasa Selatan memiliki lebih dari 10.000 ha kawasan hutan dan kayu cempaka sekitar 1.000 ha di Kecamatan Tareran yang dikenal sebagai komunitas "RumoongLansot". Penanaman cempaka, nantu dan jenis kayu lain secara besar-besaran dilaksanakan di tahun 1980-an diinsiasi oleh Dinas Kehutanan Propinsi Sulawesi Utara. Berdasarkan informasi yang diperoleh dari hasil wawancara juga diketahui bahwa bahan baku yang digunakan dalam industri pembuatan rumah adat Minahasa di Desa Tombasian (Kabupaten Minahasa) sebagian besar berasal dari Kecamatan Tareran (Minahasa Selatan). Beberapa hal tersebut dapat menginidikasikan bahwa masyarakat Minahasa Selatan telah sangat mengenal jenis tanaman cempaka sejak lama, sehingga memberikan pengaruh sangat nyata terhadap pengetahuan awal yang dimiliki peserta pelatihan. Hal ini dapat diketahui dari rata-rata pre test peserta yang memiliki nilai paling tinggi. Peserta dari Kabupaten Minahasa Selatan memiliki pengetahuan awal lebih baik mengenai cempaka dibandingkan pengetahuan peserta dari Kabupaten Minahasa dan Minahasa Utara, sehingga berakibat terhadap rendahnya kenaikan hasil evaluasi pada level II ini dibandingkan kabupaten lainnya.

Wilayah Kabupaten Minahasa juga merupakan daerah penghasil kayu cempaka di Sulawesi Utara, namun pemanfaatan cempaka di wilayah ini tidak sebaik pengembangannya di daerah Minahasa Selatan. Berdasarkan informasi yang diperoleh diketahui bahwa tegakan cempaka yang berada di Kabupaten Minahasa sebagian berasal dari pengembangan tegakan cempaka dari daerah Minahasa Selatan. Benih-benih cempaka asal wilayah Minahasa Selatan banyak digunakan sebagai materi perbanyakan cempaka di wilayah Minahasa. Hal ini berkorelasi postif terhadap pengetahuan peserta pelatihan yang dimiliki masyarakat dari Kabupaten Minahasa.

Masyarakat Kabupaten Mianahasa Utara memiliki tingkat pengetahuan awal yang paling rendah mengenai teknik penanaman cempaka, hal ini kemungkinan disebabkan karena pemanfaatan cempaka di wilayah Minahasa Utara masih sangat terbatas. Wilayah Minahasa Utara lebih didominasi tanaman kelapa dibandingkan tanaman kayu, khususnya cempaka. Sehingga masyarakat Minahasa sangat minim berinteraksi dengan tanaman cempaka. Hasil ini dapat menjelaskan bahwa tingkat interaksi masyarakat terhadap satu hal akan memberikan pengaruh pada tingkat pengetahuan yang dimiliki. Semakin lama masyarakat berinteraksi dengan tanaman cempaka maka secara alami pengetahuan yang dimiliki masyarakat juga semakin tinggi.

Berdasarkan hasil rekapitulasi dari pertanyaan-pertanyaan yang diberikan kepada peserta pelatihan dalam pre test (Gambar 2) dapat diketahui bahwa pertanyaan mengenai karakteristik tanaman cempaka (pertanyaan 3 ) dan pengetahuan mengenai pola agroforestry tanaman cempaka (pertanyaan 10) memiliki nilai yang paling rendah jika dibandingkan pertanyaan lainnya.

Secara umum informasi mengenai karakteristik tanaman cempaka yang tidak tahan terhadap kekeringan tidak banyak dikatahui peserta pelatihan. Cempaka sebagai tanaman yang sensitif perlu pelakuan khusus dalam pengembangannya. Informasi mengenai hal ini yang disampaikan saat 
kegiatan pelatihan sangat bermanfaat bagi peserta, sehingga antisipasi terhadap kondisi yang tidak sesuai dengan karakteristik pertumbuhan cempaka dapat dilakukan sebelum memulai kegiatan penanaman cempaka. Irawan et al., (2019) menyatakan bahwa cempaka wasian merupakan jenis tanaman yang memiliki tingkat ketahanan paling rendah terhadap kondisi kekeringan dibandingkan dengan jenis mahoni dan nantu.

Pemanfaatan tanaman cempaka menggunakan pola agroforestry juga tidak banyak diketahui peserta sebelum pelaksanaan pelatihan. Premono \& Lestari (2013) menyatakan bahwa pola penanaman campuran (agroforestry) merupakan bentuk efisiensi yang dilakukan petani dengan tujuan untuk mengurangi biaya dan menambah keragaman hasil lahan. Melalui pengembangan pola agroforestry, masyarakat masih dapat memperoleh hasil tanaman musiman secara berkelanjutan tanpa berpengaruh signifikan terhadap pertumbuhan tanaman utama. Pola ini juga mampu memberikan solusi bagi terbatasnya lahan yang dimiliki masyarakat terkait keinginannya mengembangkan tanaman cempaka. Komoditas yang berpotensi untuk dikembangkan menggunakan pola ini adalah pengembangan jenis vanili dibawah tegakan cempaka. Jenis ini memiliki potensi yang baik, mengingat banyak masyarakat yang saat ini mengembangkannya. Selain manfaat ekonomi keberadaan jenis tanaman sela mampu memberikan kontribusi terhadap pertumbuhan tinggi dan diameter cempaka. Handayani dan Junaidi (2014) meyatakan bahwa pola agroforestry dapat meningkatkan kandungan $\mathrm{C}$ organik dalam tanah, sehingga berakibat meningkatkan porositas tanah dan kapasitas lapang. Lebih lanjut disampaikan bahwa dampak pola tanam agroforestry sengon bersifat positif terhadap pertumbuhan tegakan sengon khususnya meningkatkan diameter dan tinggi pohon sengon. Selain itu Mindawati et al. (2013) juga mayampaikan bahwa pola agroforestry mampu memberikan hasil pertumbuhan sengon yang terbaik dibandingkan dengan monokultur sengon

Kedua informasi tersebut dapat menjadi hal berharga dari hasil kegiatan pelatihan ini. Porsi penyampaian kedua informasi tersebut dapat lebih mendalam dibandingkan penyampaian informasi lainnya untuk kegiatan serupa selanjutnya. Pemahaman terhadap kedua informasi ini diduga mampu meningkatkan minat masyarakat untuk melestarikan tanaman cempaka, khusunya informasi mengenai pemanfaatan cempaka menggunakan pola agroforestry.

\section{KESIMPULAN DAN SARAN}

\section{Kesimpulan}

Pelatihan tenik penanaman cempaka dapat terlakasana dengan baik (evaluasi level 1). Pelatihan mampu meningkatkan pengetahuan peserta yang ditandai dengan adanya peningkatan nilai hasil evaluasi dari kuesioner sebelum dan setelah pelatihan sebesar 22\% di Kabupaten Minahasa; 20\% di Kabupaten Minahasa Utara, dan 13\% di Kabupaten Minahasa Selatan (evaluasi level II).

\section{Saran}

Pelaksanan pelatihan perlu dilakukan terhadap kalangan anak muda dengan konsep yang menarik sehingga mampu mendorong pengembangan cempaka secara lebih luas.

\section{UCAPAN TERIMA KASIH}

Ucapan terima kasih kami sampaikan kepada Kepala BP2LHK Manado, Mochlis. S. Hut.T, MP dan koordinator ITTO (International Tropical Timber Organitation), Diah Irawati Dwi Arini, S.Hut, M.Sc sehingga penelitian ini dapat terlaksana dengan baik. Kegiatan pelatihan teknik penanaman cempaka ini didanai oleh ITTO melalui project ITTO PD 646/12 Rev 3 (F). Initiating Initiating The Conservation Of Cempaka Tree Species (Elmerrillia Spp) Through Plantation Development With Local Community Participation In North Sulawesi, Indonesia

\section{DAFTAR RUJUKAN}

Falola, H.O., Osibanjo,A.O., Ojo, S.I., (2014). Effectiveness of training and development on employees performance and organization competitiveness in the Nigerian Banking Industry, Bulletin of the Transilvania University of Braşov, 7 (56), 162-170. 
Handayani, W., \& Junaidi, E. (2014). Dampak Pola Tanam Agroforestry Sengon Terhadap Karakteristik Tanah. Makalah ini Telah Di Terbitkan pada Prosiding Seminar Nasional Agroforestri ke5, Balai Penelitian Teknologi Agroforestry.

Irawan, A., Hidayah, H, N., \& Mindawati, N. (2019). Pengaruh Perlakuan Cekaman Kekeringan Terhadap Pertumbuhan Semai Cempaka Wasian, Nantu, Dan Mahoni. Jurnal Penelitian Kehutanan Wallacea, 8(1), 39-45.

Kinho, K \& Mahfudz. (2011). Prospek Pengembagan Cempaka di Sulawesi Utara. Manado : Balai Penelitian Kehutanan Manado, 2011.

Lumempouw, F. (2014). Proses pembuatan rumah menurut adat di daerah tombulu. Kajian Komunitas Adat dan Budaya Bahari. pp. 117-130. ISSN 978-19365-

04.http://repo.unsrat.ac.id/471/1/proses_pembuatan_rumah_menurut_adat_di_daerah_tom bulu.pdf.

Meilya,I, R., \& Syamsi, I. (2015). Evaluasi Program Pelatihan In-House Training Pembelajaran Paket C Di Sanggar Kegiatan Belajar Jawa Tengah. Jurnal Pendidikan dan Pemberdayaan Masyarakat, 2(2), $156-174$.

Mindawati, N., Kosasih, A.S, Bustomi, S, Sitompul S.M. \& Tyasmoro, S.Y. (2013). Pola Agroforestry untuk Meningkatkan Fungsi Ekologi dan Agroekonomi Hutan Rakyat. Prosiding Seminar Nasional Agroforestri 2013, tanggal 21 Mei 2013 di Malang. Hal.189196. Kerjasama Balai Penelitian Teknologi Agroforestry, Fakultas Pertanian Universitas Brawijaya, ICRAF dan Masyarakat Agroforestri Indonesia. Ciamis.

Nangi, J., \& Palelu, J. (2016). A survey of termite subterranean (Isoptera) of an cempaka-wasian plantation in South Minahasa District, North Sulawesi, Indonesia. Prosiding Seminar Nasional Inovasi Hasil Penelitian Pendidikan dan Gagasan Kreatif Hal 9 - 22, Bali, Pustaka Larasan.

Premono, B,T., \& Lestari, S. (2013). Analisis finansial agroforestri kayu bawang (Dysoxilum Mollissimum Blume) dan kebutuhan lahan minimum di provinsi bengkulu. Jurnal Penelitian Sosial dan Ekonomi Kehutanan, 10(4):211-223

Sasmuko, S, A. (2010). Karakteristik kayu lokal untuk rumah woloan di provinsi sulawesi utara. Jurnal Penelitian Hasil Hutan, 28(3), 278-290.

Sulaefi. (2017). Pengaruh pelatihan dan pegembangan terhadap disiplin kerja dan kinerja karyawan. Jurnalmanajemen dan kewirausahaa, 5(1), 8-21.

Sultana, A., Irum,S., Ahmed,K.,\& Mehmood, N. (2012), Impact of training on employee performance: a study of telecommunication sector in Pakistan. Interdisciplinary journal of contemporary research in business, 4 (6), 646-661

Tahir, N., Yousafzai, I.K., Jan, S., \& Hashim, M. (2014), The impact of training and development on employees performance and productivity a case study of United Bank Limited Peshawar City, KPK, Pakistan, International Journal of Academic Research in Business and Social Sciences, 4 (4), 86-98.

Utomo, A, P., \& Tahupeioru, K, P. (2014). Evaluasi Pelatihan dengan Metode Kirkpatrick Analysis. Jurnal Telemetika, 9(2), 37-41, 21-30.

Wardhani, C,H., Sumartono., \& Makmur, M. (2015) Manajemen penyelenggaraan program pelatihan masyarakat (studi di balai besar pemberdayaan masyarakat dan desa kementerian dalam negeri di malang),Jurnal Sosial dan Humaniora, 18 (1),

Yuliarmi, N.N. \& Riyasa, P. (2007). Analisis faktor-faktor yang mempengaruhi kepuasan pelanggan terhadap pelayan-an PDAM Kota Denpasar. Jurnal Buletin Studi Ekonomi, 12 (1), 1-10 